\title{
Impact of Storage Time on Characteristics of Synthetic Greywater for Two Different Pollutant Strengths to Be Treated or Recycled
}

\author{
S. N. Abed • S. A. Almuktar • M. Scholz $\mathbb{D}$
}

Received: 1 December 2019 / Accepted: 15 April 2020 / Published online: 30 April 2020

(C) The Author(s) 2020

\begin{abstract}
Storage of greywater is controversial for environmental and health reasons. Artificial greywater was assessed after 2 and 7 days of storage time. Two different greywater pollutant strengths were statistically compared at each storage time. A negative significant $(p<0.05)$ correlation was evident with increasing storage time for
\end{abstract}

Electronic supplementary material The online version of this article (https://doi.org/10.1007/s11270-020-04602-1) contains supplementary material, which is available to authorized users.

S. N. Abed · S. A. Almuktar · M. Scholz $(\bowtie)$

Civil Engineering Research Group, School of Computing, Science and Engineering, The University of Salford, Newton Building, Salford, England M5 4WT, UK

e-mail: miklas.scholz@tvrl.lth.se

S. N. Abed

e-mail: suhail.najem@gmail.com

S. A. Almuktar

e-mail: suhad.suhad81@yahoo.com

\section{S. A. Almuktar}

Department of Architectural Engineering, Faculty of Engineering, The University of Basrah, Al-Basrah, Iraq

\section{Scholz}

Division of Water Resources Engineering, Department of Building and Environmental Technology, Faculty of Engineering, Lund University, P.O. Box 118, 22100 Lund, Sweden

M. Scholz

Department of Civil Engineering Science, School of Civil Engineering and the Built Environment, University of Johannesburg, Kingsway Campus, PO Box 524, Aukland Park, Johannesburg 2006, South Africa the 5-day biochemical oxygen demand for more than 2 days. However, the concentrations of 5-day biochemical oxygen and chemical oxygen demands reduced significantly at 2 days of storage when compared with freshly prepared greywater. Biodegradability (5-day biochemical oxygen demand/chemical oxygen demand ratio) decreased significantly after storage to between 0.14 and 0.39 . The nitrification process was improved significantly with increasing storage time concerning low strength greywater with a significant increase in the removal of ammonianitrogen and a non-significant decrease in the removal of nitrate-nitrogen. The correlation was significantly positive between ammonia-nitrogen and 5-day biochemical oxygen demand for stored greywater, while it was significantly negative between total suspended solids and both 5-day biochemical oxygen demand and dissolved oxygen. Significant reductions in colour, total suspended solids and turbidity were correlated positively with storage time. Precipitation of dissolved metals was suspected to occur in storing greywater by binding the inorganic components with the sediment and collide surfaces through adsorption, allowing a significant drop in concentrations of dissolved and undissolved metals with increasing storage time through sedimentation. Synthetic greywater of low mineral pollution had significantly higher removals for almost all concentrations compared with those for high concentrations. More advanced technologies for high trace element removal are required.

Keywords Biodegradability - Contamination load · Heavy metals · Hydraulic retention time · Sustainability . Mineral analysis 


\section{Introduction}

Decentralised wastewater treatment systems are commonly applied in suburban areas, where locals recycle their effluents for non-drinking end uses such as garden watering (Musazura et al. 2018). Meanwhile, the generated fresh wastewater may be collected and stored in situ before treatment (Liu et al. 2010). Domestic wastewater has been widely treated on-site within small neighbourhoods using constructed wetlands, especially greywater originating from household washing activities (Paulo et al. 2013; Barzegar et al. 2019). Constructed wetlands are a nature-based treatment technology, which is low in investment, operation and maintenance costs as well as high in ecosystem services (Scholz and Lee 2005). All types of engineered treatment wetlands have a specifically designed treatment capacity and each treatment cycle requires a time period to store and possibly treat wastewater, known as the hydraulic retention time (Vymazal 2010). Implementations of constructed wetlands for greywater treatment have been reported in many countries such as in the UK (FrazerWilliams et al. 2008), Germany (Nolde 2005), Israel (Gross et al. 2007) and Costa Rica (Dallas et al. 2004), achieving high average removal rates of pollutants with moderate hydraulic retention times.

Greywater is commonly reused for irrigation in agriculture and the flushing of toilets (Jefferson et al. 2004). The crucial requirement for recycling of greywater is to ensure that both the treatment approach and storage time lead to good water quality fulfilling the relevant standards linked health concerns (WHO 2006).

Characteristics of greywater significantly vary depending on many factors such as point of generation, community demographics, human habits, level of occupation, culture and geographical zone (Eriksson et al. 2002; Hasani et al. 2019). Moreover, detergents, cosmetics and other chemical products could also contribute to the variation of the quality of greywater and its pollutant content (Eriksson et al. 2003; Barzegar et al. 2019). Kitchen effluents also affect the organic load, nutrients, pathogens and other pollutants within greywater (AlJayyousi 2003). Another reason for fluctuations within greywater quality is the concentration of metals and other elements that mainly relate to household chemicals and the status of supplied water from the pumping station to the consumer throughout the storage tanks and water network (Nolde 2005). Eriksson et al. (2002) have indicated notably high levels of zinc in greywater. Heavy metals are mainly associated with beautifying creams, body care lotion and other cosmetic industry products (Bocca et al. 2014). Varying concentrations of metals were recorded in discharges of baths, showers and hand-wash basins. Fluctuations in trace elements are common in natural waste products such as human hair (Chojnacka et al. 2012). Although researchers have excluded some wastewater resources from greywater, metals have been found to some extend in kitchen and dishwasher effluents (Kariuki et al. 2012). Elevated sodium levels have been discovered in laundry wastewater compared with greywater from other sources. Sodium in greywater is often linked to several anionic surfactants contained within cleaning products, for example, sodium chloride as ion-exchanger (Jefferson et al. 2004). Consequently, the properties of greywater treated in any system vary due to both the background and time of production as well as changes of characteristics during retention time. It has been reported that storage of greywater over a 4-h period leads to a reduction of the $\mathrm{BOD}_{5}$ by half. However, greywater quality can be degraded due to the growth of microorganism at long residence times (Jefferson et al. 2004). Dissolved oxygen can be consumed by rapidly developing bacterial populations within greywater after about $48 \mathrm{~h}$ of storage time (Dixon et al. 2000).

Storing and reusing of greywater are linked to a risk of spreading diseases due to the possibility of pathogen presence. Nevertheless, this risk is significantly less than for black water comprising predominantly domestic wastewater (Eriksson et al. 2002; Abed et al. 2019). It has been indicated that a significant number of bacteria have grown when greywater was stored for $72 \mathrm{~h}$ (March and Gual 2009; Abdel-Shafy et al. 2019).

Using raw greywater for watering of plants presents a probable hazard to watercourses, due containing of bacteria and viruses, raw greywater could be a source of spreading diseases (WHO 2006). Greywater may impact on both filter media and soil characteristics by breakdown of the corresponding structure and clogging. Studies analysing the content of greywater during storage and just before reuse are rare. However, it is known that chemical products in real greywater have varying decomposition rates during storage due to several biochemical activities ( $\mathrm{Li}$ et al. 2009; Liu et al. 2010). Furthermore, some of the engineering treatment techniques fail to achieve greywater treatment targets, since they have been designed for fresh wastewater without considering the degradation in water quality during the storage stage (Winward et al. 2008). In contrast, 
improvement in the removal of contaminated substances from greywater such as undissolved matter has not been investigated (Liu et al. 2010; Paulo et al. 2013). Greywater could be stored for subsequent recycling (e.g. irrigation) or be treated by in situ blue-green solutions such as wetland systems, which, however, require a relatively long hydraulic retention time for treatment. International thresholds for safe reuse of wastewater and greywater, which have been published by FAO (2003) and WHO (2006), could be considered as criteria for greywater either to be reused for irrigation or to be treated and then discharged to water bodies. Therefore, in order to fill this knowledge gap, the objectives of this article are to (a) understand the behaviour and stability of key greywater components at different hydraulic retention times before treatment; (b) assess the water quality of different synthetic greywaters after storing it for 2 and 7 days under outdoor conditions; and (c) compare measurements linked to objective (b) with properties of corresponding fresh artificial greywater.

\section{Materials and Methods}

\subsection{Synthetic Greywater}

Two chemical formulae have been adopted to produce greywater artificially (Abed and Scholz 2016) by selecting technical-grade chemicals supplied by Fisher Scientific Co. Ltd. (Bishop Meadow Road, Loughborough, UK). Under non-sterilised laboratory ambient conditions, synthetic greywater was prepared according to two chemical recipes as stock solutions based on tap water (Online Resource 1). The calcium and magnesium hardness of the tap water was only about $0.01 \%$ of the quantity of calcium, which was added as part of the artificial greywater. The resulting quality of the greywater resembled the water quality characteristics of real greywater at low (LC) and high (HC) contamination strengths. However, biological contamination including pathogens was not included in the design composition of synthetic greywater. Biomass degradation would consume oxygen and make the stock solution instable, and therefore unsuitable for benchmarking purposes. The stock solutions were stored for the next day at $4{ }^{\circ} \mathrm{C}$. Before use, they were agitated for half an hour, and tap water was added at the desired dilution ratios (Abed and Scholz 2016; Nghiem et al. 2006).

\subsection{Experimental Set-up}

The experiment was located on the roof of the Newton Building (53 $23^{\prime} 09.3^{\prime \prime} \mathrm{N}$ and $2^{\circ} 16^{\prime} 24.8^{\prime \prime} \mathrm{W}$ ), the University of Salford, Greater Manchester, UK. The research work commenced in September 2014 and finished in January 2016. The analysis of water quality (section 2.3) was performed in November 2014; after 60 days allowing for biofilm development; then the water tests were performed in batches every 2 and 7 days of the storage time for each test group (Fig. 1). Plastic buckets of 141 were filled with 101 of fresh greywater for both LC and HC pollutant concentration experiments. The operational system comprised two groups; the first one was designed to store HC-greywater for 2 and 7 days (each set had four replicates), and the second group stored LC-greywater for the same storage time with four replicates for each set as shown in Fig. 1. The data were compared individually for fresh LCgreywater with their results after 2- and 7-day storage time, and the same scenario was repeated for $\mathrm{HC}-$ greywater as described in section 2.4.

\subsection{Greywater Quality Measurements}

The artificial greywater quality was examined following APHA (2005) unless mentioned else. After storage, 11 of greywater was taken from each group of the system in triplicates. The standardised water analysis included colour, total suspended solids (TSS), ortho-phosphatephosphorus $\left(\mathrm{PO}_{4}-\mathrm{P}\right)$, nitrate-nitrogen $\left(\mathrm{NO}_{3}-\mathrm{N}\right)$, ammonia-nitrogen $\left(\mathrm{NH}_{4}-\mathrm{N}\right)$ and the chemical oxygen demand (COD). The spectrophotometer DR 2800 Hach Lange (www.hach.com) was used for these variables. A mono-metric measurement device (OxiTop IS 12-6 system produced by the Wissenschaftlich-Technische Werkstätten (WTW), Weilheim, Germany) was purchased to evaluate the 5-day biochemical oxygen demand $\left(\mathrm{BOD}_{5}\right)$ for all samples. A METTLER TOLEDO FIVE GOTM conductivity meter (Keison Products, Chelmsford, Essex, England, UK) for electric conductivity (EC) and a Turbicheck Turbidity Meter (Lovibond Water Testing, Tintometer Group) for turbidity measurements were also utilised. The hydrogen ion $(\mathrm{pH})$ and redox potential $(\mathrm{Eh})$ were evaluated by a sensION+ benchtop multi-parameter meter (Hach Lange, Düsseldorf, Germany). A HQ30d Flexi Meter (Hach Lange, Düsseldorf, Germany) was applied to determine dissolved oxygen (DO). 


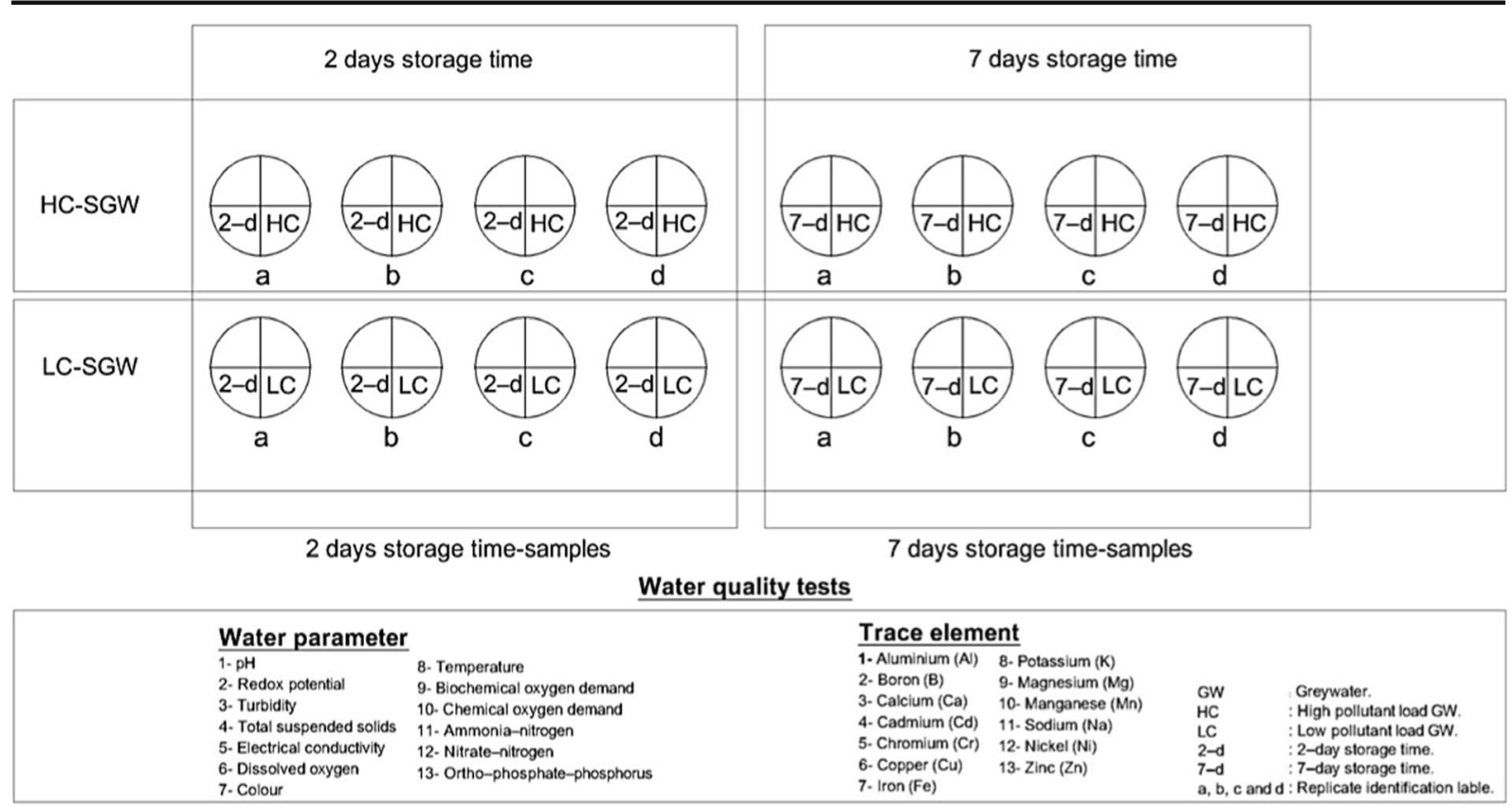

Fig. 1 Schematic of the detailed experimental set-up

The minerals and trace element content of fresh and stored greywater were analysed according to "SW-846: Test Method 6010D" (USEPA 2014) for elemental analysis of waters and wastes using an Inductively Coupled Plasma-Optical Emission Spectrometry (ICP-OES) by Varian 720-ES (Agilent Technologies UK Ltd., Wharfedale Road, Wokingham, Berkshire, UK). Triplicate samples of $10 \mathrm{ml}$ greywater were filtered using a cellulose paper filter of $0.45-\mu \mathrm{m}$ pore diameter and then acidified before analyses (USEPA 1994).

For calibration purposes, identical reagents and magnitudes as those used in preparing water samples were facilitated as blank samples, which were occasionally tested to verify the detection limit with the theoretical concentration values. Avoidance of instrumental drifts was ensured by operating three solutions of standard calibration intermediately between the samples in the detection process of various metal concentrations.

\subsection{Statistical Examination}

The routine data calculations were undertaken within Microsoft Excel using the functional options such as minimum, maximum, arithmetical mean and standard deviation. The Statistical Package for the Social Sciences (IBM-SPSS) Statistics Version 23 analysed all datasets at 95\% confidence level. Variables of interval-scale with approximate normal distributions were compared by the independent $t$ test of the two independent samples. The data distribution was examined by the Kolmogorov-Smirnov and Shapiro-Wilks tests for normality (Collis and Hussey 2013). If the hypothesis of normality is rejected, then the analysis must be operated by non-parametric techniques using the Mann-Whitney test. The Spearman's test was applied to assess the correlations among variables.

\section{Results and Discussion}

\subsection{Physiochemical Characteristics}

Properties of fresh greywater including physiochemical characteristics and trace element concentrations for LC and $\mathrm{HC}$ are shown in Online Resource 2. The $\mathrm{pH}$ value of LC-greywater ranged between 5.3 and 7.9, which complied with those reported values originating from discharge with separated sources such as bathroom (Samayamanthula et al. 2019) and mixed sources of greywater ( $\mathrm{Li}$ et al. 2009). The $\mathrm{pH}$ values of $\mathrm{HC}-$ greywater (5.4-11.5) were comparable with real effluents, which are usually produced from laundries (Eriksson et al. 2002; Li et al. 2009) and compatible with the other published findings of artificially prepared greywater (Nghiem et al. 2006). Almost all studies lacked redox potential (Eh) data linked to real greywaters. 
The EC values are elevated in real greywaters, particularly for laundries and mixed sources (Samayamanthula et al. 2019). They match the higher limits of EC measured for HC-greywater (612$1677 \mu \mathrm{S} / \mathrm{cm})$. In contrast, the low values of EC in LCgreywater $(99-452 \mu \mathrm{S} / \mathrm{cm})$ agreed with those values of real greywater obtained from bathrooms and hand-wash basins (Al-Hamaiedeh and Bino 2010; Leal et al. 2012).

Fresh greywater showed a wide range in measurements of colour for LC-greywater (26-340 $\mathrm{Pa} / \mathrm{Co})$ and HC-greywater (787-2499 Pa/Co), which is not uncommon for real greywater as well. Regarding temperature, both types of greywater were also similar to real greywater (Eriksson et al. 2002). Turbidity and TSS values of fresh LC-greywater (mean, 22.9; range, 9.841.6 and mean, $39.9 \mathrm{mg} / \mathrm{l}$; range, $10.0-87.0 \mathrm{mg} / \mathrm{l}$, respectively) agreed with reported values (Al-Jayyousi 2003; Eriksson et al. 2010; March et al. 2004; Pidou et al. 2008; Ramona et al. 2004). Turbidity (mean, 189; range, 18-308) and TSS (mean, $317 \mathrm{mg} / \mathrm{l}$; range, 173-473 mg/l) HC-greywater values were similar to greywater discharge from kitchens, laundries and mixed sources (Al-Hamaiedeh and Bino 2010; Samayamanthula et al. 2019).

The water quality of both greywater types after storage is shown in Table 1. The statistical analysis of TSS, turbidity and colour has shown significant reductions $(p<0.05)$ in LC-greywater at both storage times compared with the corresponding values of fresh LCgreywater (Table 2). For HC-greywater, the statistical evaluation indicated non-significant increases $(p>0.05)$ in values of turbidity and TSS and a non-significant decrease in colour after 2 days of storage. However, the drops in values of turbidity and TSS were not significant $(p>0.05)$ after 7 days of storage. An insignificant elevation $(p>0.05)$ in colour value compared with fresh HC-greywater was also noted.

Reductions in the number of undissolved particles and colloids were not significant $(p>0.05)$ in stored HC-greywater, because no coagulation and flocculation process were performed in this experiment. The latter physical and chemical processes would have led to a decrease in TSS and turbidity (Nolde 2005; AbdelShafy et al. 2019). In contrast, biodegradation can lead to a rise in turbidity (Günther 2000), colour and fine particles due to the development microorganisms and degradation products as biochemical processes occur when storing greywater (Eriksson et al. 2002). Flocculation processes occur when the negative charges of colloidal particles neutralise in the presence of iron and aluminium hydrous oxides, which have positive electrical charges. This leads to aggregation and subsequently sedimentation (Barzegar et al. 2019). The colour of water is also impacted on by colloidal and noncolloidal suspended organics in combination with earth minerals (Gross et al. 2006, 2007; Li et al. 2009).

The increase in storage time led to a significant drop $(p<0.05)$ in TSS concentrations for HC-greywater after 7 days of storage compared with the value after 2 days of storage time. No significant changes in colour and turbidity were noted (Table 3 ). Regarding storage of LC-greywater, the means of TSS and turbidity reduced significantly $(p<0.05)$ within stored vessels after 7 days in comparison with those values after 2 days of storage. No significant effect on colour was noted. Storing LCgreywater has significantly affected $(p<0.05)$ drops in values of colour, turbidity and TSS compared with HCgreywater at both storage times (Table 3 ). The reduction in TSS could be explained by the physical process of sedimentation. Particles that are heavier than water will settle due to gravitational forces (Eriksson et al. 2002; Samayamanthula et al. 2019). Settling of particles is promoted after floc formation (Barakat 2011). On the contrary, microorganisms may increase the measured TSS after more than $48 \mathrm{~h}$ (Al-Jayyousi 2003).

\subsection{Oxygen Demand}

Parameters indicating oxygen demand and organic strength of fresh greywater were statistically evaluated and compared with corresponding values after storage for 2 and 7 days. Table 2 indicates that the (5 days) $\mathrm{BOD}_{5}$ concentrations of stored greywater are significantly lower than those values for both $\mathrm{HC}$-greywater and LC-greywater in this experiment (Fig. 2a).

The $\mathrm{BOD}_{5}$ concentrations of LC-greywater decreased significant $(p<0.05)$ after 2 and 7 days of storage: from 17.6 to $5.6 \mathrm{mg} / 1$ and from 17.6 to $6.7 \mathrm{mg} / \mathrm{l}$, respectively (Fig. 2a). In comparison, the $\mathrm{BOD}_{5}$ concentration for $\mathrm{HC}$-greywater significantly reduced $(p<0.05$ ) from 34.7 to $14.7 \mathrm{mg} / \mathrm{l}$ after 2 days of retention time resulting in $58 \%$ reduction. Furthermore, it reduced to $16.6 \mathrm{mg} / \mathrm{l}$ after 7 days, which equates to a reduction rate of $52 \%$ (Fig. 2b). Microbial degradation processes are the principle reason for the consumption of organic matter, which leads to higher respiration and therefore to an increase in $\mathrm{BOD}_{5}$ (Friedler et al. 2006; Maiga et al. 2014). It is possible that the drops in $\mathrm{BOD}_{5}$ 


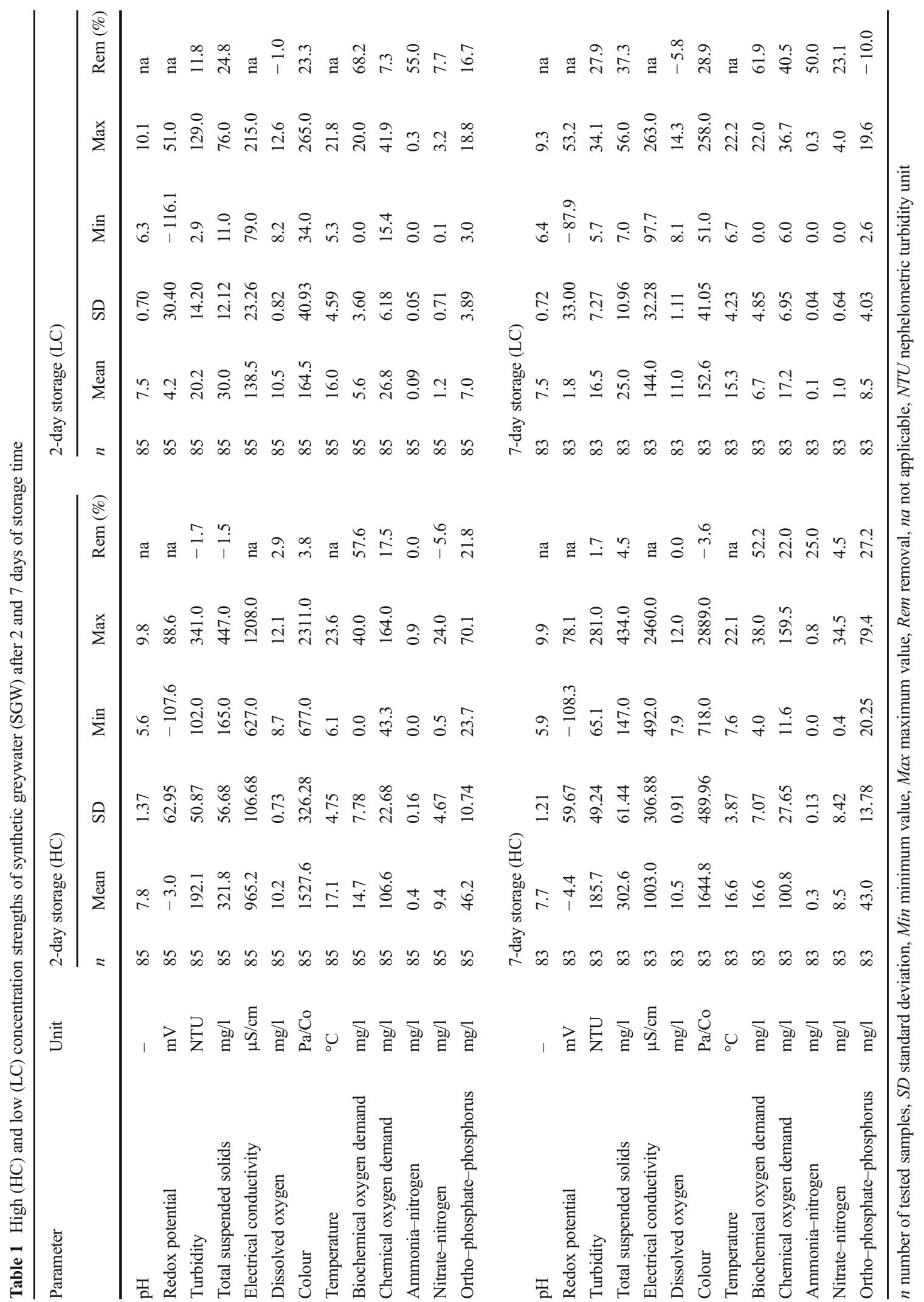




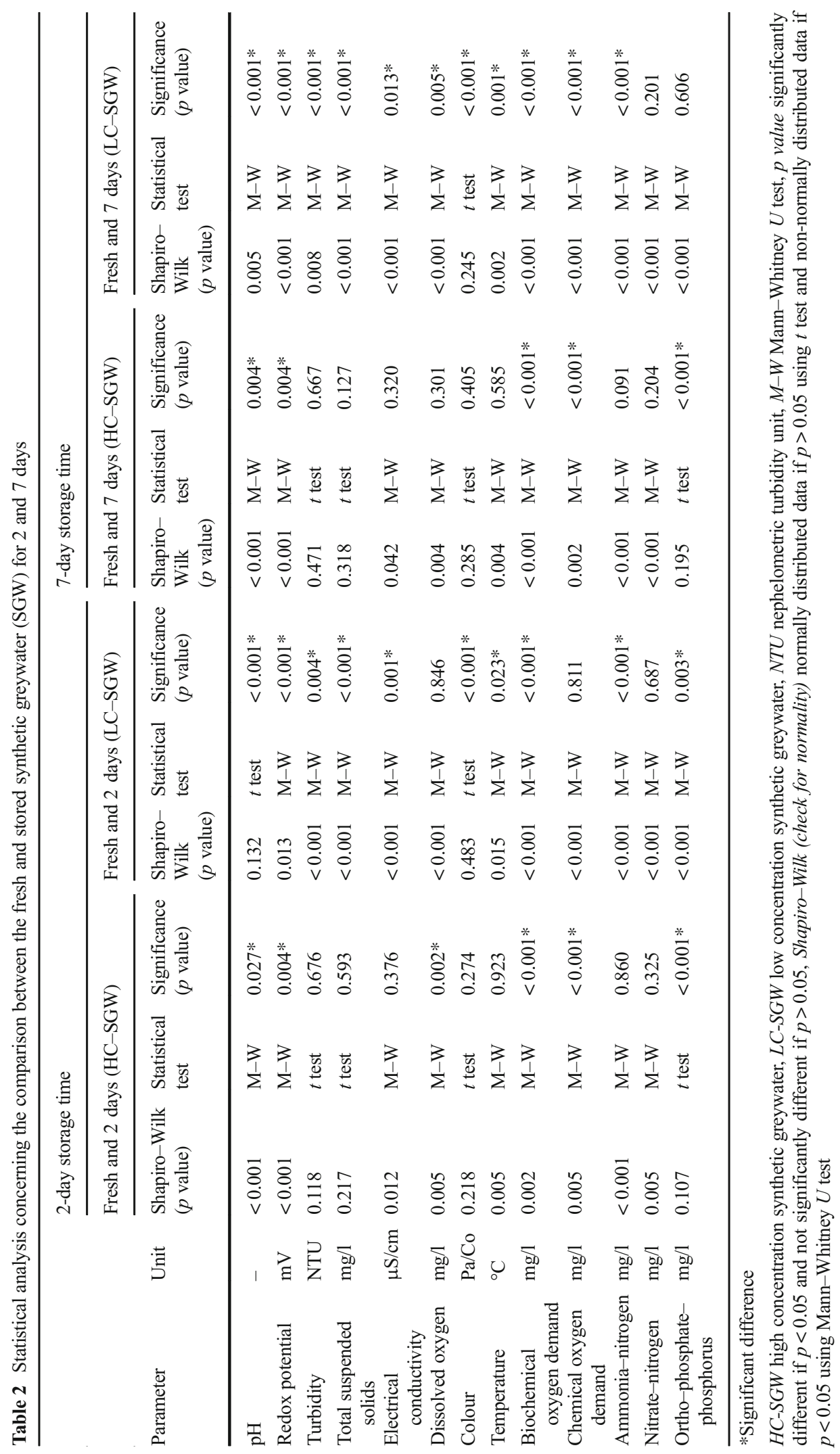




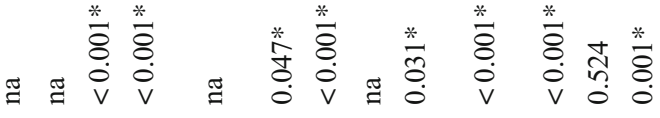

苞

焉:

$\stackrel{5}{5}$

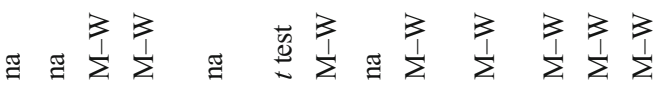

兽

焉

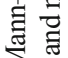

$\sum$ 苞

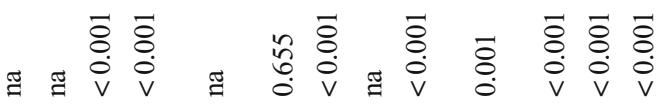

$\sum$ io

跑

密

* * * * * * *

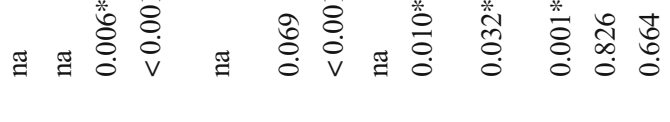

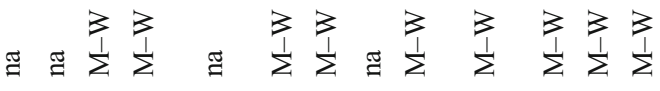

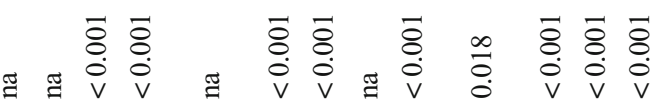

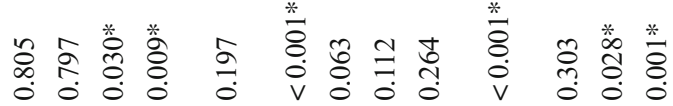

䔾

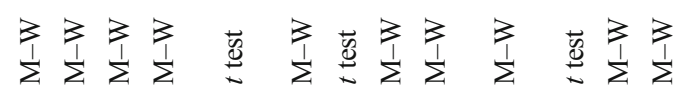

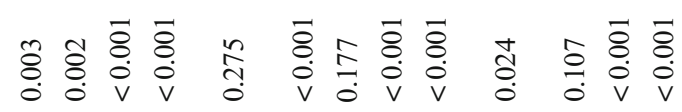

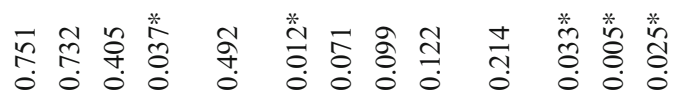

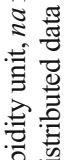

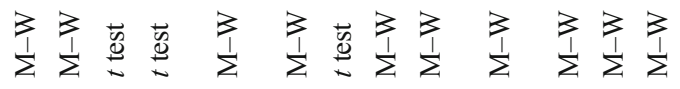



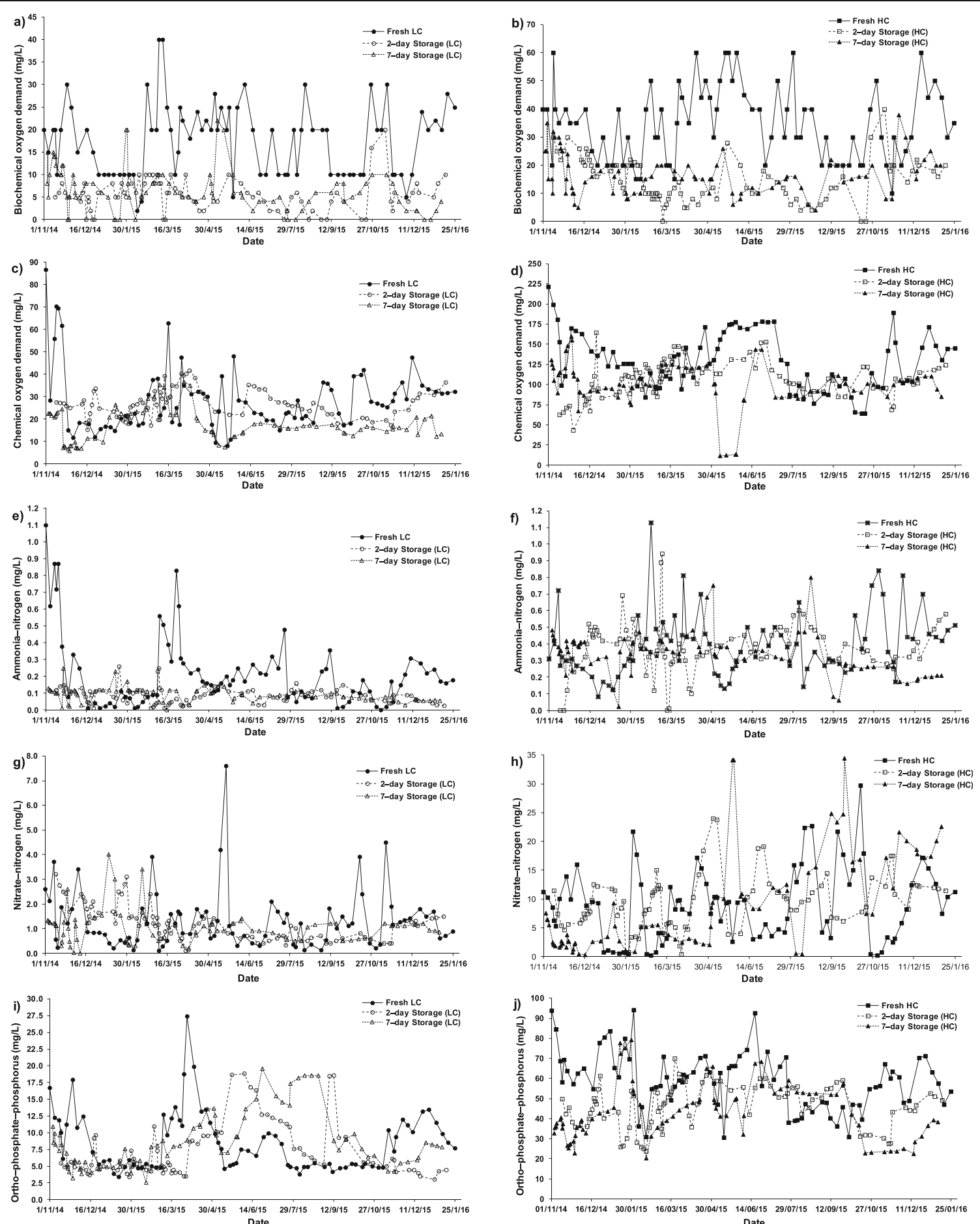

Fig. 2 Effect of storage time on the characteristics of a 5-day biochemical oxygen demand $\left(\mathrm{BOD}_{5}\right)$ for low concentrations $(\mathrm{LC})$; b $\mathrm{BOD}_{5}$ for high concentrations (HC); c chemical oxygen demand (COD) for $\mathrm{LC}$; $\mathbf{d}$ COD for $\mathrm{HC}$; e ammonia-nitrogen $\left(\mathrm{NH}_{4}-\mathrm{N}\right)$ for

$\mathrm{LC} ; \mathbf{f} \mathrm{NH}_{4}-\mathrm{N}$ for $\mathrm{HC} ; \mathbf{g}$ nitrate-nitrogen $\left(\mathrm{NO}_{3}-\mathrm{N}\right)$ for $\mathrm{LC} ; \mathbf{h} \mathrm{NO}_{3}-$ $\mathrm{N}$ for $\mathrm{HC}$; $\mathbf{i}$ ortho-phosphate-phosphorus $\left(\mathrm{PO}_{4}-\mathrm{P}\right)$ for $\mathrm{LC}$; and $\mathbf{j}$ $\mathrm{PO}_{4}-\mathrm{P}$ for $\mathrm{HC}$ of synthetic greywater 
were also caused by sedimentation, since, $\mathrm{BOD}_{5}$ statistically correlated with TSS (Abed et al. 2019).

The statistical evaluation in Table 3 shows that there was no significant effect $(p>0.05)$ when extending the storage time by more than 2 days on the $\mathrm{BOD}_{5}$ values. This is in contrast with Nolde (2005) who observed that the $\mathrm{BOD}_{5}$ concentration increased when increasing the storage time. Low levels of organic matter in greywater and insufficient numbers of microorganisms could lead to low $\mathrm{BOD}_{5}$ values (Eriksson et al. 2002; Leal et al. 2012).

The $\mathrm{BOD}_{5}$ concentrations for LC-greywater (mean of $17.6 \mathrm{mg} / \mathrm{l}$ ) were less than the stated ones for many real greywater samples. However, they matched those showed by Eriksson et al. (2010) and Winward et al. (2008). Furthermore, the investigation indicated that the $\mathrm{BOD}_{5}$ decreased significantly in systems storing LCgreywater (storage of 2 and 7 days) compared with the corresponding values of systems for $\mathrm{HC}$-greywater (both storage time also) as shown in Table 3.

An appraisal of the COD values for fresh $\mathrm{HC}-$ greywater compared with stored ones indicated significant declines $(p<0.05)$ for both retention times. The COD reduced from 129.2 to $106.6 \mathrm{mg} / \mathrm{l}$ (reduction of $17.5 \%$ ) and from 129.2 to $100.8 \mathrm{mg} / \mathrm{l}$ (reduction of $22.0 \%$ ) at 2 and 7 days of storage, respectively. The variation in COD concentrations of both greywater types can be explained by the great variety of the chemical compositions, which are used in the artificial greywater to mimic the ingredients of domestic products and detergents, which is responsible for the fluctuation in greywater test results (Al-Jayyousi 2003; Eriksson et al. 2010; Drennan et al. 2019). This variation in COD values might be influenced by its corresponding biodegradable fractions (Essington 2004; Friedler et al. 2005). Concentrations of COD of the sored LCgreywater decreased non-significantly $(p>0.05)$ after 2 days of storage, while they dropped significantly to $17.2 \mathrm{mg} / \mathrm{l}$ after 7 days of storage (Fig. 2b).

An increase of storage time effected significantly the reduction in COD concentrations for LC-greywater, while no significant change was indicated when storing HC-greywater at increasing storage times (Fig. $2 \mathrm{c}$ and d). For all retention systems, the COD removals from LC-greywater were significantly low $(p<0.05)$ compared with the eliminations of COD in HC-greywater and at both storage times (Table 3 ).

Significantly negative correlations $(p<0.01)$ were calculated between $\mathrm{BOD}_{5}$ and $\mathrm{COD}$, while the correlations became significantly positive after 7 days of storage. The correlation examination of systems storing $\mathrm{LC}$-greywater showed that $\mathrm{BOD}_{5}$ and $\mathrm{COD}$ were not correlated at both storage times. In aquatic ecosystems, reductions in $\mathrm{BOD}_{5}$ and $\mathrm{COD}$ contents were related to the consumption of oxygen due to oxidation and decomposition processes (Vymazal 2010).

The biodegradation of fresh LC-greywater and HCgreywater was also evaluated based on the ratio of $\mathrm{BOD}_{5}$ to COD, which were 0.61 and 0.27 for the former and the later in this order. Similar low ratios have been stated for greywater by Jefferson et al. (2001). Research on treating greywater by biological techniques indicated that biodegradability could be limited at low organic loads (Abdel-Shafy et al. 2019). The stimulation of biological processes has been encouraged by adding macronutrients and trace nutrients to greywater to enhance treatment (Jefferson et al. 2001). The wastewater could possibly be treated biologically when the $\mathrm{BOD}_{5}$ to COD ratio is between 0.4 and 0.8 as suggested for municipal wastewater (Abdel-Shafy et al. 2019). The $\mathrm{BOD}_{5}$ to $\mathrm{COD}$ ratio for $\mathrm{HC}$-greywater decreased, reaching 0.14 at 2 days and 0.16 at 7 days of storage. Greywater of low strength, which commonly originates from hand-washing basins and showers, has shown low concentrations of $\mathrm{BOD}_{5}$ and COD (Avery et al. 2007; Jefferson et al. 2004; Abed et al. 2019).

\subsection{Nutrients}

Fresh synthetic greywater (both formulae) resembled real greywater well. However, Table 1 shows deficiencies in nutrient balance and organic load due to the exclusion of toilet discharge (Abed and Scholz 2016). A correct nutrient balance for the biological degradation of wastewater is important. Ratios for COD:N:P of 100:20:1 or 100:5:1 are commonly proposed and discussed by Hamza et al. (2019). Nutrient deficiency has been revealed in greywater and their impact on limiting the biological processes in greywater treatment was examined by Jefferson et al. (2001, 2004). Therefore, adjusting the proportion of nitrogen to phosphorus by adding sufficient organic substances may lead to the improvement of oxygen demand removals (Al-Jayyousi 2003).

A statistical comparison of results for fresh and stored greywater is shown in Table 2. For HCgreywater, the $\mathrm{NH}_{4}-\mathrm{N}$ concentrations were relatively stable at $0.4 \mathrm{mg} / \mathrm{l}$ with no significant $(p>0.05)$ 
alterations at both storage times, compared with fresh HC-greywater. In contrast, a significant difference $(p<0.05)$ in concentrations of $\mathrm{NH}_{4}-\mathrm{N}$ in systems storing LC-greywater for 2 and 7 days (Fig. 2e) was noted compared with fresh LC-greywater. An increase of storage time had no significantly $(p>0.05)$ impact on concentrations of $\mathrm{NH}_{4}-\mathrm{N}$ in the retention systems storing LC-greywater. In system comprising $\mathrm{HC}-$ greywater, a significant $(p<0.05)$ drop in concentration of $\mathrm{NH}_{4}-\mathrm{N}$ with an increase of storage time from 2 to 7 days was observed (Fig. 2f). The removal of $\mathrm{NH}_{4}-\mathrm{N}$ in LC-greywater was significantly $(p<0.05)$ higher than in HC-greywater at both storage times.

A significant positive correlation $(p<0.01)$ was noted between the concentrations of $\mathrm{NH}_{4}-\mathrm{N}$ and $\mathrm{COD}$ for fresh greywater regrading both formulas. For systems storing LC-greywater, the $\mathrm{NH}_{4}-\mathrm{N}$ concentration correlated significantly negative $(p<0.01)$ with COD at 2 days of storage and significantly positive $(p<0.01)$ with $\mathrm{BOD}_{5}$ at 7 days of storage. For $\mathrm{NH}_{4}-\mathrm{N}$, the measured values were close to the detection limit. Therefore, it is a challenge to observe nitrification and denitrification processes in the data (Essington 2004).

No significant alterations $(p>0.05)$ were noted when comparing the $\mathrm{NO}_{3}-\mathrm{N}$ values of both types of fresh greywater with the corresponding values for stored greywater (Table 2). The fluctuations in trend were carefully monitored for $\mathrm{NO}_{3}-\mathrm{N}$ concentrations at both times of storage for $\mathrm{HC}$-greywater. The concentrations increased slightly from 8.9 to $9.4 \mathrm{mg} / \mathrm{l}$ at 2 days of storage and subsequently decreased to reach $8.5 \mathrm{mg} / \mathrm{l}$ after 7 days of storage time. The $\mathrm{NO}_{3}-\mathrm{N}$ concentration of LC-greywater reduced slightly from 1.3 to $1.2 \mathrm{mg} / \mathrm{l}$ and to $1.0 \mathrm{mg} / \mathrm{l}$ after storage of 2 and 7 days, respectively (Fig. $2 \mathrm{~g}$ ). An increase of the storage time had a significant effect $(p<0.05)$ on decreasing the $\mathrm{NO}_{3}-\mathrm{N}$ values for both types of greywater (Figs. $2 \mathrm{~g}$ and $1 \mathrm{~h}$ ).

The removal rate of $\mathrm{NO}_{3}-\mathrm{N}$ at both storage times was statistically insignificant $(p>0.05)$ (Table 3$)$. The increase of $\mathrm{NO}_{3}-\mathrm{N}$ can be explained by the nitrification process taking place (Essington 2004). An inefficient removal of nitrogenous compounds was either due to insufficient organic content and/or a lack in number of surviving denitrifying bacteria, which are both associated with greywater ( $\mathrm{Li}$ et al. 2009).

In comparison, for fresh and stored greywater in terms of ortho-phosphate-phosphorus $\left(\mathrm{PO}_{4}-\mathrm{P}\right)$, significant $(p<0.05)$ decreases were observed in all storage systems except for systems retaining LC-greywater for 7 days
(Fig. 2i and Table 2). Decreases from $59.1 \mathrm{mg} / \mathrm{l}$ for fresh HC-greywater to $46.2 \mathrm{mg} / \mathrm{l}$ (lowering by $21.8 \%$ ) for 2 days of storage and from 46.2 to $43.0 \mathrm{mg} / \mathrm{l}$ (reduction of $27.2 \%$ ) for 7 days of storage were calculated. For fresh LC-greywater, decreases from 8.4 to $7.0 \mathrm{mg} / 1$ for a 2-day storage time were noted. Furthermore, concerning 7-day storage of LC-greywater, concentrations remained virtually unchanged (Fig. 2j).

An increase in storage time affected significantly $(p<0.05)$ the decline of $\mathrm{PO}_{4}-\mathrm{P}$ for both types of greywater of low and high pollutant strengths (Table 3). The removal of $\mathrm{PO}_{4}-\mathrm{P}$ in systems storing LC-greywater was higher than for HC-greywater (Figs. $2 \mathrm{i}$ and $1 \mathrm{j}$ ). This is due to the fact that storage time allows particles to settle. Therefore, a significant $(p<0.01)$ positive correlation was detected between TSS and $\mathrm{PO}_{4}-\mathrm{P}$ for all systems. The dominant mechanism of $\mathrm{PO}_{4}-\mathrm{P}$ removal in such systems is sedimentation of heavy particles, while fine materials can settle after flocculation (Jefferson et al. 2001). In wetlands, the phosphorus fraction, which is absorbed by plants, is significantly lower than nitrogen (Avery et al. 2007). Furthermore, the open environment is likely to be another cause for the development of microbes within the storage systems consuming phosphorus (Friedler et al. 2006; Paulo et al. 2013). Since microorganisms were not deliberately introduced to the artificial greywater, microbial biomass developed rather slowly. Therefore, microbial activities accounted for only a small proportion of phosphorus removal (Abdel-Shafy et al. 2019).

\subsection{Minerals and Trace Elements}

Fresh and stored greywater samples were analysed to identify trace metal concentrations (Online Resource 2 and Table 4). The statistical comparisons of metal concentrations between the fresh and the stored greywater showed that $\mathrm{Fe}, \mathrm{Mg}$ and $\mathrm{Na}$ concentrations were stable around their mean values for all storage systems (Table 5). A study initiated for comparison purposes revealed that $\mathrm{B}, \mathrm{Cd}, \mathrm{Cu}$ and $\mathrm{Zn}$ concentrations did not alter significantly $(p>0.05)$ for systems storing HCgreywater. For both systems storing $\mathrm{HC}$-greywater and $\mathrm{LC}$-greywater, concentrations of $\mathrm{Al}$ and $\mathrm{Cr}$ at 2 days of storage time and $\mathrm{Ca}, \mathrm{Cd}$ and $\mathrm{Zn}$ at 7 days of retention did not significantly $(p>0.05)$ change compared with their values for fresh greywater (Fig. 3). It has been reported that the existence of metal oxy-hydroxides of $\mathrm{Mg}, \mathrm{Fe}$ and $\mathrm{Al}$ as well as ground minerals in wastewater 
Table 4 Chemical analysis of trace element concentrations (mg/l) of low (LC) and high (HC) concentration strengths of synthetic greywaters (SGW) stored for 2 and 7 days

\begin{tabular}{|c|c|c|c|c|c|c|c|c|c|c|c|c|}
\hline \multirow[t]{2}{*}{ Element } & \multicolumn{6}{|c|}{ 2-day storage (HC) } & \multicolumn{6}{|c|}{ 2-day storage (LC) } \\
\hline & $n$ & Mean & SD & Min & Max & $\operatorname{Rem}(\%)$ & $n$ & Mean & $\mathrm{SD}$ & Min & Max & $\operatorname{Rem}(\%)$ \\
\hline Aluminium & 39 & 2.41 & 1.016 & 0.74 & 4.25 & -13.15 & 39 & 0.34 & 0.180 & 0.11 & 0.72 & 34.62 \\
\hline Boron & 35 & 0.54 & 0.060 & 0.42 & 0.66 & 5.26 & 35 & 0.11 & 0.009 & 0.08 & 0.13 & 21.43 \\
\hline Calcium & 37 & 43.02 & 2.411 & 35.94 & 46.28 & -19.24 & 46 & 11.25 & 0.773 & 9.86 & 12.70 & -6.74 \\
\hline Cadmium & 42 & 7.69 & 1.064 & 4.95 & 8.98 & -4.48 & 42 & 0.05 & 0.031 & 0.00 & 0.11 & 44.44 \\
\hline Chromium & 58 & 3.76 & 1.203 & 1.34 & 4.98 & -17.5 & 58 & 0.04 & 0.049 & 0.00 & 0.12 & 0.00 \\
\hline Copper & 63 & 1.45 & 0.113 & 1.28 & 1.70 & -0.69 & 63 & 0.06 & 0.049 & 0.02 & 0.15 & 62.50 \\
\hline Iron & 51 & 6.35 & 2.423 & 1.56 & 9.29 & 0.94 & 51 & 0.21 & 0.157 & 0.09 & 0.45 & 0.00 \\
\hline Potassium & 14 & 55.68 & 4.486 & 49.48 & 60.69 & 7.45 & 14 & 3.87 & 0.364 & 3.35 & 4.50 & 4.21 \\
\hline Magnesium & 48 & 17.76 & 1.392 & 13.92 & 19.55 & -0.20 & 48 & 1.35 & 0.133 & 0.99 & 1.58 & 6.90 \\
\hline Manganese & 63 & 1.19 & 0.063 & 1.06 & 1.29 & -21.4 & 63 & 0.08 & 0.056 & 0.00 & 0.18 & 52.94 \\
\hline Sodium & 14 & 58.19 & 10.620 & 42.35 & 68.22 & 7.16 & 14 & 13.82 & 1.175 & 12.14 & 15.57 & 3.49 \\
\hline Nickel & 53 & 0.03 & 0.018 & 0.00 & 0.06 & 40.00 & 53 & 0.01 & 0.007 & 0.00 & 0.04 & 75.00 \\
\hline \multirow[t]{2}{*}{ Zinc } & 44 & 4.30 & 0.524 & 3.12 & 5.25 & -1.42 & 42 & 0.09 & 0.083 & 0.00 & 0.23 & 57.14 \\
\hline & \multicolumn{6}{|c|}{ 7-day storage (HC) } & \multicolumn{6}{|c|}{ 7-day storage (LC) } \\
\hline Aluminium & 54 & 2.98 & 1.218 & 1.61 & 6.14 & -39.91 & 44 & 0.36 & 0.189 & 0.09 & 0.75 & 30.77 \\
\hline Boron & 26 & 0.54 & 0.160 & 0.34 & 0.77 & 5.26 & 24 & 0.12 & 0.064 & 0.08 & 0.26 & 14.29 \\
\hline Calcium & 52 & 37.39 & 4.030 & 30.58 & 45.66 & -3.63 & 52 & 10.74 & 0.739 & 9.44 & 12.12 & -1.90 \\
\hline Cadmium & 36 & 6.40 & 1.984 & 3.86 & 9.72 & 13.59 & 32 & 0.09 & 0.083 & 0.00 & 0.21 & 0.00 \\
\hline Chromium & 46 & 4.76 & 1.215 & 2.83 & 6.68 & -48.75 & 42 & 0.07 & 0.074 & 0.00 & 0.21 & -75.00 \\
\hline Copper & 54 & 1.30 & 0.301 & 0.80 & 1.76 & 9.72 & 48 & 0.10 & 0.091 & 0.00 & 0.26 & 37.50 \\
\hline Iron & 42 & 7.02 & 1.801 & 3.58 & 9.36 & -9.52 & 38 & 0.20 & 0.100 & 0.07 & 0.30 & 4.76 \\
\hline Potassium & 8 & 45.77 & 5.160 & 39.87 & 51.00 & 23.92 & 8 & 3.62 & 0.438 & 3.07 & 4.22 & 10.40 \\
\hline Magnesium & 54 & 16.24 & 1.971 & 11.76 & 18.35 & 5.36 & 46 & 1.38 & 0.161 & 1.03 & 1.64 & 4.83 \\
\hline Manganese & 54 & 1.01 & 0.223 & 0.75 & 1.38 & -3.06 & 48 & 0.06 & 0.074 & 0.00 & 0.21 & 64.71 \\
\hline Sodium & 8 & 55.22 & 11.852 & 41.86 & 67.68 & 11.90 & 8 & 13.15 & 1.199 & 11.83 & 14.36 & 8.17 \\
\hline Nickel & 50 & 0.09 & 0.081 & 0.00 & 0.20 & -80.00 & 44 & 0.05 & 0.080 & 0.00 & 0.18 & -25.00 \\
\hline Zinc & 32 & 3.90 & 0.972 & 1.90 & 5.10 & 8.02 & 28 & 0.13 & 0.068 & 0.01 & 0.25 & 38.10 \\
\hline
\end{tabular}

$n$ number of tested samples, $S D$ standard deviation, Min minimum value, Max maximum value, Rem removal

could demobilise or decompound metals via various processes (Fu and Wang 2011; Hua et al. 2012). The pH value and redox potential impact on the cation and anion exchanges have major roles in terms of biological availability of dissolved metals. However, chemical reactions between numerous products in wastewater could lead to unpredictable results (Barakat 2011; Fu and Wang 2011). Sedimentation might not be a straight-forward physical process concerning trace element removal, except if they are part of large suspended particles. Other processes like complexation, precipitation and co-precipitation might have to happen first (Abed et al. 2019).
Regardless of storage time, significant reductions $(p<0.05)$ in $\mathrm{B}$ and $\mathrm{Cu}$ concentrations were detected in systems comprising LC-greywater. The same was the case for $\mathrm{K}$ concentrations in systems of $\mathrm{HC}$-greywater for both times of storage. At 2 days of storage times for LC-greywater, $\mathrm{Cd}, \mathrm{Cr}$, Ni and $\mathrm{Zn}$ values were significantly $(p<0.05)$ removed, and $\mathrm{Ca}$ and $\mathrm{Fe}$ concentrations were significantly elevated compared with those concentrations of fresh LC-greywater (Table 5). In addition, only a significant increase in Ni content was noted after storing LC-greywater for 7 days compared with fresh LC-greywater. For HC-greywater, 


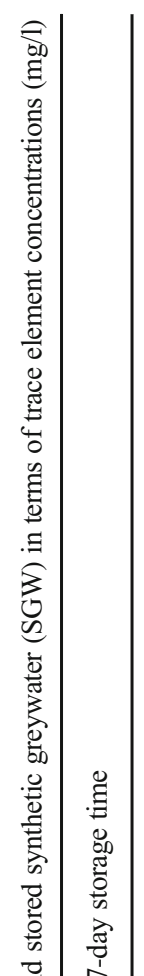

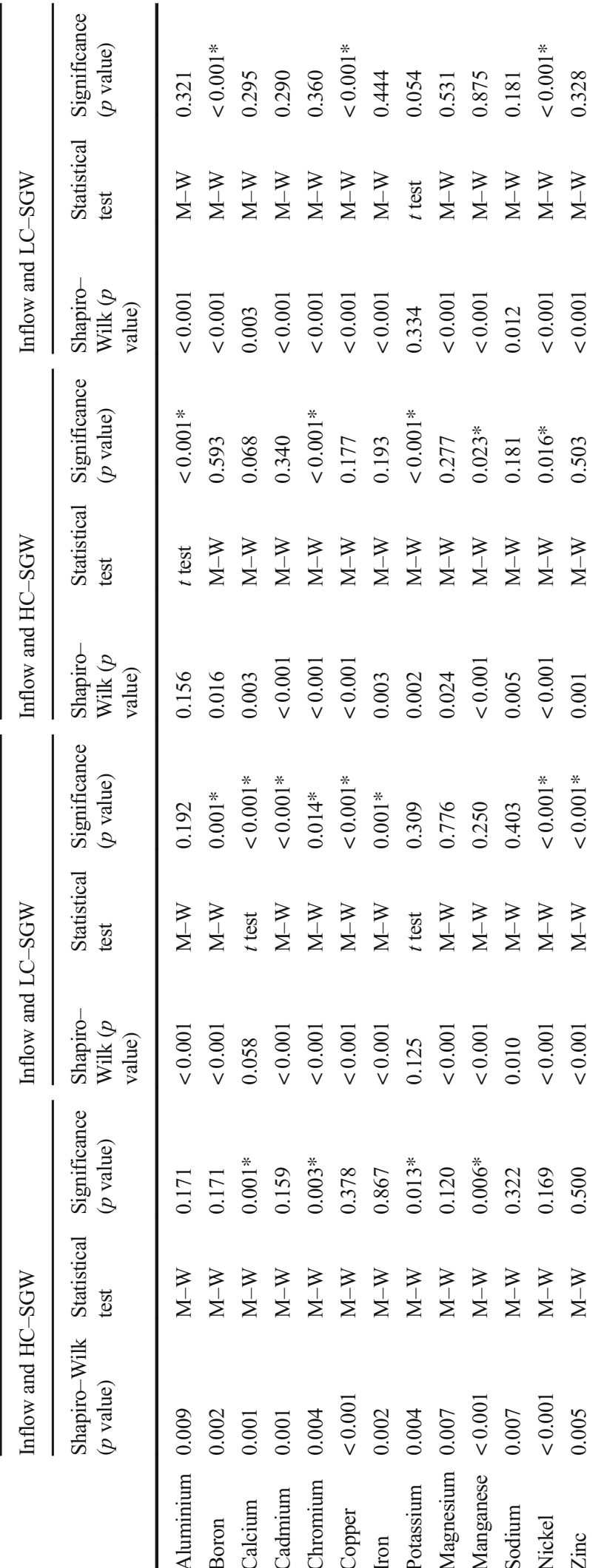



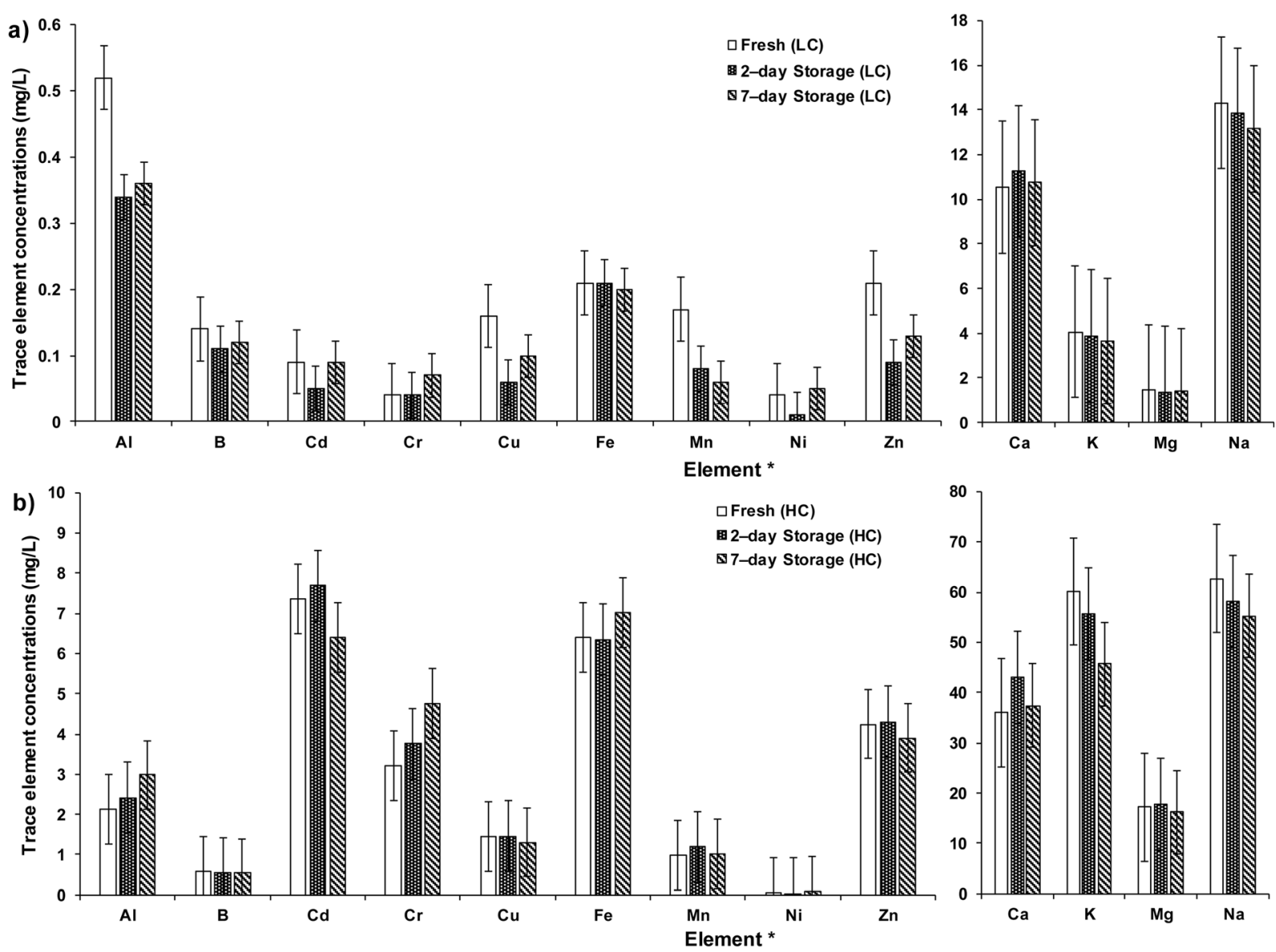

* Al aluminium, B boron, Cd Cadmium, Crchromium, Cu copper, Fe iron, Mn manganese, Ninickel, Zn zinc, Ca calcium, $\mathrm{K}$ potassium, Mg magnesium, Na sodium

Fig. 3 Effect of storage time on the variation of the average concentration of trace elements for both types of synthetic greywater (SGW): a low concentrations (LC) and $\mathbf{b}$ high concentrations (HC)

significant increases were noted for concentrations of $\mathrm{Ca}$ after storage for 2 days. Furthermore, significant increases were recorded for $\mathrm{Al}$ and $\mathrm{Ni}$ after 7 days as well as for $\mathrm{Cr}$ and $\mathrm{Mn}$ but for both times compared with those concentrations in the fresh HC-greywater (Table 5).

The main mechanism of calcium reaction in water is erosion under normal conditions (Essington 2004). During the 2 days of storage, it could be the dissolved calcium hydroxide was created in the presence of the calcium components in water, then hydrogen gas could highly possible to be produced (Hua et al. 2012). The solubility of calcium carbonate increased five times in the presence of carbon dioxide due to the formulation of carbonic acid resulting in calcium hydrogen carbonate (Wan et al. 2018). The stability of calcium ion exchange was observed after 2 days of storage time.

Organic constituents of high molecular weight can be stimulated to precipitate at the presence of hydrous oxides of metals such as $\mathrm{Al}, \mathrm{Fe}$ and $\mathrm{Mg}$. The elemental contamination in water is generally either dissolved or forms part of particles. Dissolved metal precipitation could occur when binding inorganic contaminants in various chemical reactions to the sediment and colloid surfaces through adsorption processes (Hua et al. 2012). The process of sedimentation becomes possible only after floc formation (Abed et al. 2017, 2019). With the development of a blanket of flocs, which have surface electronic charges, sedimentation of fine pollutant particles becomes likely (Hua et al. 2012).

Regarding the effect of increasing storage time on the trace element concentrations (Table 6), greywater samples from storage systems with 7 days were statistically compared with values of greywater after 2 days of storage time. $\mathrm{Al}, \mathrm{B}, \mathrm{Cd}, \mathrm{Cr}, \mathrm{Cu}, \mathrm{Fe}, \mathrm{K}, \mathrm{Mg}, \mathrm{Na}, \mathrm{Ni}$ and $\mathrm{Zn}$ concentrations did not change significantly $(p>0.05)$ in stored LC-greywater. Increasing 

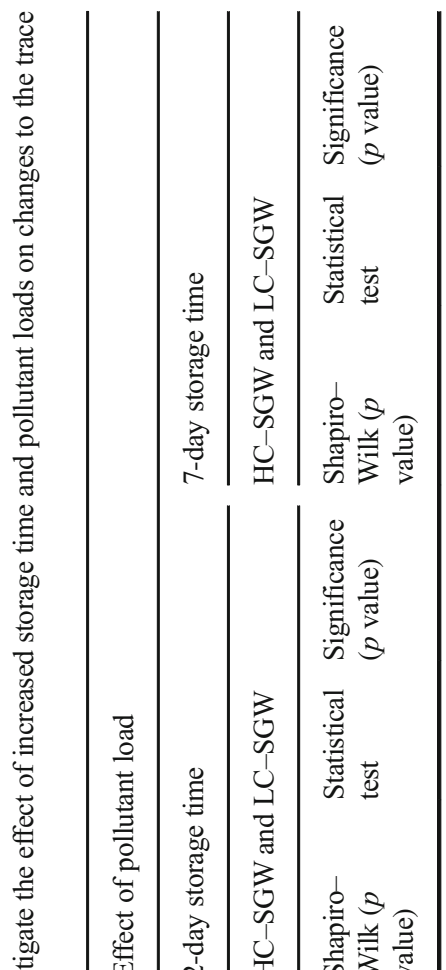

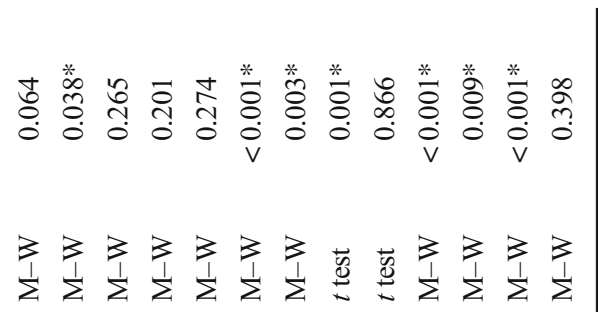

$\stackrel{\circ}{\supset}$

芩.

?

计

$2 \sum_{\substack{\infty \\ 0}}^{\mathrm{N}}$

気.

题 है

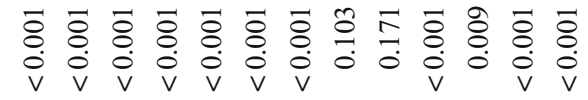

窟

绻

就

芠

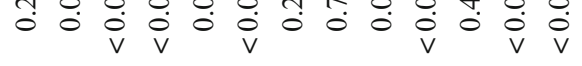

苍

$>$ 을

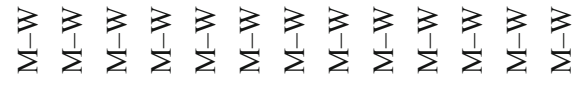

害弯

龸

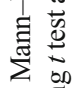

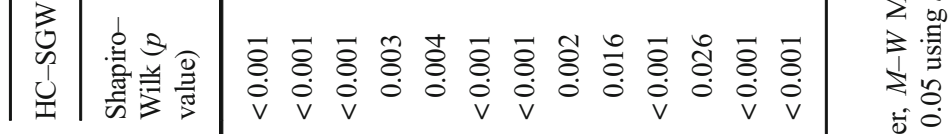

.

$\stackrel{+}{8}$

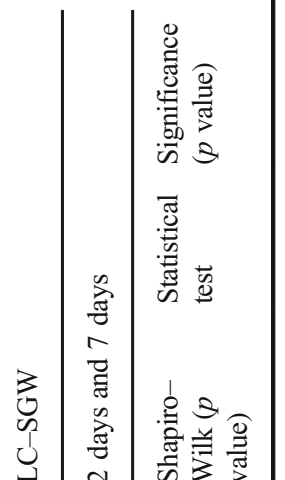

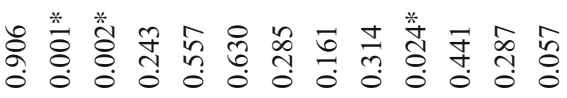

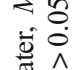

$\sum_{0}^{\pi} \hat{2}$

离営

窇兽

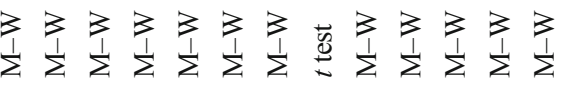

홍ำ

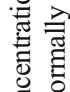

亏

을

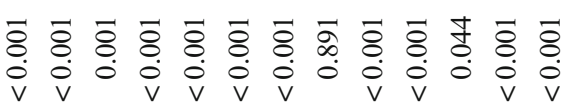

苍

पी

है

党

穷

.

营 क

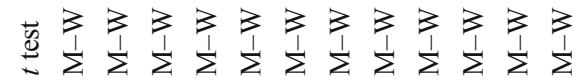

荟官

党 $\hat{\imath}$

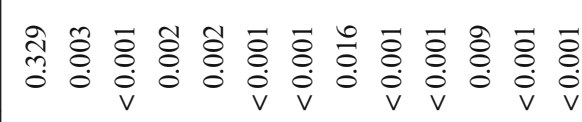

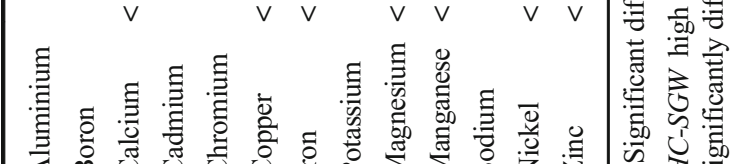

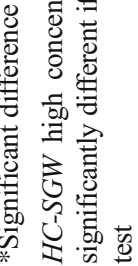


concentrations of $\mathrm{B}, \mathrm{Fe}, \mathrm{Na}$ and $\mathrm{Zn}$ for systems storing HC-greywater were noted. Significant $(p<0.05)$ reductions of $\mathrm{Ca}$ and $\mathrm{Mn}$ in stored $\mathrm{LC}$-greywater and also significant decreases in $\mathrm{Ca}, \mathrm{Cd}, \mathrm{Cu}, \mathrm{K}, \mathrm{Mg}$ and $\mathrm{Mn}$ for stored $\mathrm{HC}$-greywater were recorded. When storing $\mathrm{HC}$-greywater for 7 days, an increase in storage time led to significant $(p<0.05)$ rises of $\mathrm{Al}, \mathrm{Cr}$ and $\mathrm{Ni}$ concentrations as shown in Table 6 and Fig. 3.

An increase in storage time allows for biological degradation of organic matter, which consumes dissolved oxygen and changes the redox and $\mathrm{pH}$ conditions. Degradation of organic substances is possibly aerobically and anaerobically for those accumulated into the sediment layer, which is responsible to adsorb heavy metals and other elements from wastewater (Barakat 2011).

Significant changes $(p<0.05)$ for most trace element concentrations were higher in systems storing LCgreywater compared with those for $\mathrm{HC}$-greywater (Table 6). This is due to factors such as the high solid content and elevated $\mathrm{pH}$, which are associated with $\mathrm{HC}-$ greywater, and the corresponding environmental boundary conditions (Abed et al. 2017).

Findings indicate that more advanced technologies for trace element removal are required. Possible processes of pollutant removal in such systems may combine biodegradation and sedimentation. Flocculation, complexation, precipitation, absorption, cation and anion exchange, oxidation/reduction and microbiological activity could be possible mechanisms for removal of heavy metals (Barakat 2011). However, in the current study, the greywater was stirred before sampling to mimic the suspension of solids, resuspension of solids and sloughing-off of biofilms from the storage vessel walls.

\section{Conclusions and Recommendations}

The retention of greywater for prolonged periods of time without active treatment processes being employed leads to passive self-purification due to extended storage. Significant reductions in colour, TSS and turbidity have been achieved when greywater was stored for 7 days. Both sedimentation and biological degradation were the predominated mechanisms in removal of suspended solids due to microorganism development during storage. For long storage time periods, biodegradation can lead to a rise in turbidity, colour and fine particles due to the growth of microorganisms and the generation of degradation products during biochemical processes. Aggregation and subsequently sedimentation can be observed when flocculation processes occur due to the negatively charged colloidal particles that are neutralised in the presence of iron and aluminium hydrous oxides, which have positive electrical charges. Furthermore, it was observed that COD correlated significantly negatively with $\mathrm{BOD}_{5}$ at 2 days of storage time and significantly positively at 7 days. A significant positive correlation in removal of COD (concentrations between 60 and $220 \mathrm{mg} / \mathrm{l}$ ) was observed with storage time. Greywater biodegradability expressed by the ratio of $\mathrm{BOD}_{5}$ to COD decreased significantly after storage time to be within the range of about 0.14 and 0.39 . Extended storage supports biological treatment of greywater particularly in wetland systems.

Due to lack organic substances in greywater, nitrogen compounds had low concentrations. Significant removal of $\mathrm{NH}_{4}-\mathrm{N}$ after retention was noted for LC greywater. However, no significant changes of $\mathrm{NO}_{3}-\mathrm{N}$ were recorded. A significant positive correlation was computed between $\mathrm{NH}_{4}-\mathrm{N}$ and $\mathrm{BOD}_{5}$ after storing greywater.

Storage of greywater contributed significantly to the removal of $\mathrm{PO}_{4}-\mathrm{P}$ due to processes such as sedimentation for undissolved particles, precipitation, co-precipitation of dissolved solids and microbial activities. A significant positive correlation between concentrations of TSS and $\mathrm{PO}_{4}-\mathrm{P}$, particularly with increasing storage time, was noted. In reality, greywater has much less solids than black (waste) water coming from, for example, toilets. So, a high need for frequent sediment removal is not likely. However, a good practice engineering solution to manage sedimentation when storing greywater could be the division of the storage unit into two parts: one for sedimentation and the second for the overflow greywater to be stored, recycled or discharged. In situ constructed wetlands are highly recommended to treat greywater before recycling. The most beneficial method of recycling of nutrients within greywater is its reuse for irrigation purposes.

Acknowledgements Dr. Matthew Dennis gave scientific assistance. Carlos Verdú, Elena Manjon Alfaro, Rubén García, César Moya, Guillaume Gourdikian, Anita Paul, Claire Guillin, Guillaume Drouin and Pauline Francois contributed to the data collection. 
Funding Information Open access funding provided by Lund University.

Open Access This article is licensed under a Creative Commons Attribution 4.0 International License, which permits use, sharing, adaptation, distribution and reproduction in any medium or format, as long as you give appropriate credit to the original author(s) and the source, provide a link to the Creative Commons licence, and indicate if changes were made. The images or other third party material in this article are included in the article's Creative Commons licence, unless indicated otherwise in a credit line to the material. If material is not included in the article's Creative Commons licence and your intended use is not permitted by statutory regulation or exceeds the permitted use, you will need to obtain permission directly from the copyright holder. To view a copy of this licence, visit http://creativecommons.org/licenses/by/4.0/.

\section{References}

Abdel-Shafy, H., Mansour, M., \& Al-Sulaiman, A. (2019). Anaerobic/aerobic integration via UASB/enhanced aeration for greywater treatment and unrestricted reuse. Water Practice and Technology. https://doi.org/10.2166 /wpt.2019.065.

Abed, S. N., \& Scholz, M. (2016). Chemical simulation of greywater. Environmental Technology, 37(13), 1631-1646.

Abed, S. N., Almuktar, S. A., \& Scholz, M. (2017). Treatment of contaminated greywater using pelletised mine water sludge. Journal of Environmental Management, 197, 10-23.

Abed, S. N., Almuktar, S. A., \& Scholz, M. (2019). Phytoremediation performance of floating treatment wetlands with pelletized mine water sludge for synthetic greywater treatment. Journal of Environmental Health Science and Engineering, 372, 1-28. https://doi. org/10.1007/s40201-019-00372-z.

Al-Hamaiedeh, H., \& Bino, M. (2010). Effect of treated grey water reuse in irrigation on soil and plants. Desalination, 256, 115119.

Al-Jayyousi, O. R. (2003). Greywater reuse: towards sustainable water management. Desalination, 156, 181-192.

APHA. (2005). Standard methods for the examination of water and wastewater (21st ed.). Washington, DC: American Public Health Association (APHA), American Water Works Association (AWWA), and Water and Environment Federation (WEF).

Avery, L. M., Frazer-Williams, R. A. D., Winward, G., ShirleySmith, C., Liu, S., Memon, F. A., \& Jefferson, B. (2007). Constructed wetlands for grey water treatment. Ecohydrology and Hydrobiology, 7(3-4), 191-200.

Barakat, M. A. (2011). New trends in removing heavy metals from industrial wastewater. Arabian Journal of Chemistry, 4(4), 361-377.

Barzegar, G., Wu, J., \& Ghanbari, F. (2019). Enhanced treatment of greywater using electrocoagulation/ozonation: investigation of process parameters. Process Safety and Environmental Protection, 121, 125-132.
Bocca, B., Pino, A., Alimonti, A., \& Forte, G. (2014). Toxic metals contained in cosmetics: a status report. Regulatory Toxicology and Pharmacology, 68(3), 447-467.

Chojnacka, K., Saeid, A., Michalak, I., \& Mikulewicz, M. (2012). Effects of local industry on heavy metals content in human hair. Polish Journal of Environmental Studies, 21(6), 15631570 .

Collis, J., \& Hussey, R. (2013). Business research: a practical guide for undergraduate and postgraduate students. London: Palgrave Macmillan.

Dallas, S., Scheffe, B., \& Ho, G. (2004). Reedbeds for greywater treatment-case study in Santa Elena-Monteverde, Costa Rica, Central America. Ecological Engineering, 23(1), 5561.

Dixon, A., Butler, D., Fewkes, A., \& Robinson, M. (2000). Measurement and modelling of quality changes in stored untreated grey water. Urban Water, 1(4), 293-306.

Drennan, D., Koshy, R., Gent, D., \& Schaefer, C. (2019). Electrochemical treatment for greywater reuse: effects of cell configuration on COD reduction and disinfection byproduct formation and removal. Water Supply, 19(3), 891-898.

Eriksson, E., Auffarth, K., Henze, M., \& Ledin, A. (2002). Characteristics of grey wastewater. Urban Water, 4, 85-104.

Eriksson, E., Auffarth, K., Eilersen, A. M., Henze, M., \& Ledin, A. (2003). Household chemicals and personal care products as sources for xenobiotic organic compounds in grey wastewater. Water SA, 29(2), 135-146.

Eriksson, E., Srigirisetty, S., \& Eilersen, A. M. (2010). Organic matter and heavy metals in grey-water sludge. Water $S A$, 36(1), 139-142.

Essington, M. E. (2004). Soil and water chemistry: an integrative approach. Boca Raton: CRC Press.

FAO. (2003). User manual for irrigation with treated wastewater. Cairo: Food and Agriculture Organization (FAO) Regional office for Near East.

Frazer-Williams, R., Avery, L., Gideon, W., Jeffrey, P., ShirleySmith, C., Liu, S., \& Jefferson, B. (2008). Constructed wetlands for urban grey water recycling. International Journal of Environmental Pollution, 33(1), 93-109.

Friedler, E., Kovalio, R., \& Galil, N. I. (2005). On-site greywater treatment and reuse in multi-storey buildings. Water Science and Technology, 51, 187-194.

Friedler, E., Kovalio, R., \& Ben-Zvi, A. (2006). Comparative study of the microbial quality of greywater treated by three on-site treatment systems. Environmental Technology, 27(6), 653-663.

Fu, F., \& Wang, Q. (2011). Removal of heavy metal ions from wastewaters: a review. Journal of Environmental Management, 92(3), 407-418.

Gross, A., Kaplan, D., \& Baker, K. (2006). Removal of microorganisms from domestic greywater using a recycling vertical flow constructed wetland (RVFCW). Proceedings of the Water Environmental Federation, 2006(6), 6133-6141.

Gross, A., Kaplan, D., \& Baker, K. (2007). Removal of chemical and microbiological contaminants from domestic greywater using a recycled vertical flow bioreactor (RVFB). Ecological Engineering, 31(2), 107-114.

Günther, F. (2000). Wastewater treatment by greywater separation: outline for a biologically based greywater purification plant in Sweden. Ecological Engineering, 15(1), 139-146. 
Hamza, R. A., Zaghloul, M. S., Iorhemen, O. T., Sheng, Z., \& Tay, J. H. (2019). Optimization of organics to nutrients (COD: N: P) ratio for aerobic granular sludge treating high-strength organic wastewater. Science of the Total Environment, 650, 3168-3179.

Hasani, G., Maleki, A., Daraei, H., Ghanbari, R., Safari, M., McKay, G., Yetilmezsoy, K., Ilhan, F., \& Marzban, N. (2019). A comparative optimization and performance analysis of four different electrocoagulation-flotation processes for humic acid removal from aqueous solutions. Process Safety and Environmental Protection, 121, 103-117.

Hua, M., Zhang, S., Pan, B., Zhang, W., Lv, L., \& Zhang, Q. (2012). Heavy metal removal from water/wastewater by nanosized metal oxides: a review. Journal of Hazardous Materials, 211, 317-331.

Jefferson, B., Burgess, J. E., Pichon, A., Harkness, J., \& Judd, S. J. (2001). Nutrient addition to enhance biological treatment of greywater. Water Research, 35(11), 2702-2710.

Jefferson, B., Palmer, A., Jeffrey, P., Stuetz, R., \& Judd, S. J. (2004). Grey water characterisation and its impact on the selection and operation of technologies for urban reuse. Water Science and Technology, 50(2), 157-164.

Kariuki, F. W., Ngàngà, V. G., \& Kotut, K. (2012). Hydrochemical characteristics, plant nutrients and metals in household greywater and soils in Homa Bay Town. The Open Environmental Engineering Journal, 5, 103-109.

Leal, L. H., Soeter, A. M., Kools, S. A. E., Kraak, M. H. S., Parsons, J. R., Temmink, H., Zeeman, G., \& Buisman, C. J. N. (2012). Ecotoxicological assessment of grey water treatment systems with Daphnia magna and Chironomus riparius. Water Research, 46(4), 1038-1044.

Li, F., Wichmann, F., \& Otterpohl, R. (2009). Review of the technological approaches for grey water treatment and reuses. Science of Total Environment, 407, 3439-3449.

Liu, S., Butler, D., Memon, F. A., Makropoulos, C., Avery, L., \& Jefferson, B. (2010). Impacts of residence time during storage on potential of water saving for grey water recycling system. Water Research, 44, 267-277.

Maiga, Y., Moyenga, D., Nikiema, B. C., Ushijima, K., Maiga, A. H., \& Funamizu, N. (2014). Designing slanted soil system for greywater treatment for irrigation purposes in rural area of arid regions. Environmental Technology, 35(23), 3020-3027.

March, J. G., \& Gual, M. (2009). Studies on chlorination of grey water. Desalination, 249(1), 317-322.

March, J. G., Gual, M., \& Orozco, F. (2004). Experiences on greywater re-use for toilet flushing in a hotel (Mallorca Island, Spain). Desalination, 164(3), 241-247.

Musazura, W., Odindo, A. O., Tesfamariam, E. H., Hughes, J. C., \& Buckley, C. A. (2018). Decentralised wastewater treatment effluent fertigation: preliminary technical assessment. Water SA, 44(2), 250-257.
Nghiem, L. D., Oschmann, N., \& Schäfer, A. I. (2006). Fouling in greywater recycling by direct ultrafiltration. Desalination, 187, 283-290.

Nolde, E. (2005). Greywater recycling systems in Germany-results, experiences and guidelines. Water Science and Technology, 51(10), 203-210.

Paulo, P. L., Azevedo, C., Begosso, L., Galbiati, A. F., \& Boncz, M. A. (2013). Natural systems treating greywater and blackwater on-site: integrating treatment, reuse and landscaping. Ecological Engineering, 50, 95-100.

Pidou, M., Avery, L., Stephenson, T., Jeffrey, P., Parsons, S. A., Liu, S., Memon, F. A., \& Jefferson, B. (2008). Chemical solutions for greywater recycling. Chemosphere, 71(1), 147155.

Ramona, G., Green, M., Semiat, R., \& Dosoretz, C. (2004). Low strength graywater characterization and treatment by direct membrane filtration. Desalination, 170(3), 241-250.

Samayamanthula, D., Sabarathinam, C., \& Bhandary, H. (2019). Treatment and effective utilization of greywater. Applied Water Science, 9(4), 90. https://doi.org/10.1007/s13201019-0966-0.

Scholz, M., \& Lee, B. H. (2005). Constructed wetlands: a review. International Journal of Environmental Studies, 62(4), 421447.

USEPA. (1994). Method 200.7: determination of metals and trace elements in water and wastes by inductively coupled plasmaatomic emission spectrometry. Washington, DC: United States Environmental Protection Agency (USEPA), Revision 4.4.

USEPA. (2014). SW-846 test method 6010D: inductively coupled plasma-optical emission spectrometry (ICP-AES), U.S. Revision 4. Washington DC: United States Environmental Protection Agency (USEPA).

Vymazal, J. (2010). Constructed wetlands for wastewater treatment. Water, 2(3), 530-549.

Wan, H., Qu, J., He, T., Bu, X., Yang, W., \& Li, H. (2018). A new concept on high-calcium flotation wastewater reuse. Minerals, 8(11), 496-508.

WHO. (2006). World Health Organisation guidelines for the safe use of wastewater, excreta and greywater use in agriculture (Vol. 4). Geneva: WHO Press.

Winward, G. P., Avery, L. M., Frazer-Williams, R., Pidou, M., Jeffrey, P., Stephenson, T., \& Jefferson, B. (2008). A study of the microbial quality of grey water and an evaluation of treatment technologies for reuse. Ecological Engineering, 32(2), 187-197.

Publisher's Note Springer Nature remains neutral with regard to jurisdictional claims in published maps and institutional affiliations. 